\title{
Effect of Computer Simulations on Secondary School Students' Academic Achievement in Chemistry in Anambra State
}

\author{
Okwuduba Emmanuel Nkemakolam ${ }^{1} \bowtie$ \\ Offiah Francisca Chinelo ${ }^{2}$ \\ Madichie Chinyere Jane ${ }^{s}$ \\ ${ }^{12}$ Department of Science Education Nnamdi Azikiwe University, Awka, Anambra State, Nigeria \\ Email:en.okwuduba@unizik.edu.ng.Tel:+2348067467016 \\ 'Email:foffiah@unizik.edu.ng.Tel: +2348033424757 \\ ${ }^{3}$ Federal College of Education Technical, Umunze, Anambra State, Nigeria \\ ${ }^{3}$ Email:chinyeremadichie@yahoo.com Tel: +2348020875181
}

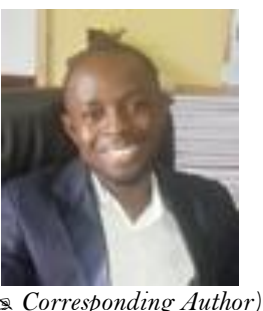

\begin{abstract}
The poor performance of students in chemistry is often blamed on inadequate practical exposure during the teaching of chemistry due to hazardous nature of some chemistry experiments. Consequently, the search for teaching method that will be used to overcome this practical constraint has continued to engage researchers. Specifically, the main purpose of this study is to determine the effects of computer simulation on academic achievement of students in chemistry. Quasi experimental research design, specifically, non-equivalent control group design was used. The sample consisted of 78 which is made up of 38 experimental group (18 males and 20 females) while control group was 40 students (16 males and 24 females) drawn from two coeducational secondary school in Awka Education zone of Anambra State. Instruments used for data collection was Chemistry Achievement Test which was pilot tested for the period of one week in another zone. Scores obtained was used to estimate the instrument reliability which was found to be 0.78 Kuder Richardson formulas 20. Two research assistants were trained in carrying out the teaching using computer simulations. Pretest was given to the students before treatment. After four weeks of teaching, a posttest was given. Mean gain was used to answer the research question while hypotheses was tested with ANCOVA to determine the significance difference. The result revealed that computer simulation was more effective in enhancing students' achievement in chemistry than lecture method; there was no significant difference on students' achievement due to gender. It was recommended that computer simulation should be adopted for teaching hazardous chemistry concepts. Based on the findings, it was concluded that computer simulation should be employed in chemistry teaching as a means of improving students' achievement in the subject and providing a real life experiment for dangerous chemistry practicals.
\end{abstract}

Keywords: Academic achievement, Chemistry concepts, Computer simulations.

Citation | Okwuduba Emmanuel Nkemakolam; Offiah Francisca Chinelo; Madichie Chinyere Jane (2018). Effect of Computer Simulations on Secondary School Students' Academic Achievement in Chemistry in Anambra State. Asian Journal of Education and Training, 4(4): 284-289. History:

Received: 25 June 2018

Revised: 2 August 2018

Accepted: 15 August 2018

Published: 20 August 2018

Licensed: This work is licensed under a Creative Commons

Attribution 3.0 License $($ (c) $)$ Er

Publisher:Asian Online Journal Publishing Group
Contribution/Acknowledgement: All authors contributed equally in the plan, design and participated actively in carrying out the study.

Funding: This study was fully funded equally by the authors.

Competing Interests: The authors declare that there is no conflict of interests among them

Transparency: The authors certify that the manuscript is an honest, accurate, and transparent account of the study which was reported. Also there is no omission of any key points in the study.

Ethical: This study follows all ethical practices during the conduct of the research and reporting of the result.

\section{Contents}

1. Introduction

2. Method

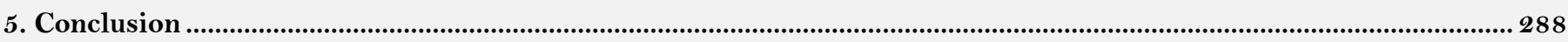

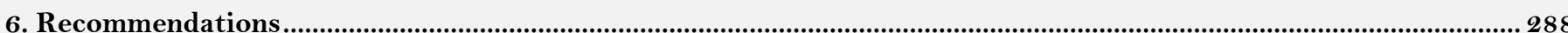

References. 


\section{Introduction}

Society Guidelines and Recommendations for the teaching of high school chemistry, 2012 stated that: Some experiments are too dangerous or impractical to be included in the hands-on laboratory curriculum. Such experiments and demonstrations may be viewed in classrooms capable of displaying video. For instance, nuclear fission reactions could be witnessed on a screen, eliminating the associated danger and required safety equipment (p.13)

It further emphasized that hands-on laboratory experiences are critical to a quality high school chemistry program and technology should not be seen as a replacement for laboratory but rather as an enhancement.

Research findings have shown that computer could be used in the classrooms to improve students' acquisition of basic skills. These can be achieved by blending text with multimedia, curriculum objectives through the use of animations and simulations to aid in demonstration (Pierce and Stacey, 2004; Adyum, 2005; Abdullahi, 2007).

It has been identified by Usman (2002) that computers can be used in three ways; as a tutor, a tutee, and a tool. When used as a tutor, the computer adapts to the student by selecting appropriate instructional resources and maintaining records of academic progress. As a tutee, the computer receives and executes instructions (in the form of programming language) from the student. As a tool, the computer is used to aid in calculation, graphical displays, animations, simulations and gaming. The main focus of this research is the use of computer for simulation purposes.

Simulations have been given different meanings by different authors; however, in a broad sense; simulations are imitations of systems. Simulations are computational models of real or hypothesized situations or natural phenomena that allow users to explore the implications of manipulating or modifying parameters within them (Clark et al., 2009). Plass et al. (2009) proposed that a simulation differs from a static visualization (example, a diagram in a textbook) because it is dynamic. It also differs from a dynamic visualization (an animation) because it allows user interaction.

Computer simulations are therefore computer- generated versions of real-world objects. Computer simulations provide near-authentic environment, context and situation for task-based learning (Chen et al., 2013). Computer simulations enable learners to view events, processes and activities, that otherwise may not have been available to them through interactive engagement. Although at first, computer simulations were mainly used in applied field, such as aviation and medic imaging, but these technologies have now edged their way into science classrooms (Kaheru et al., 2011; Quellmalz et al., 2012).

\subsection{Statement of the Problem}

The performance of the students in chemistry has been quite unsatisfactory over the years in Nigeria. The external examination body like West African Examination Council (WAEC) has repeatedly reported a steady decline in the performance of students in chemistry. The picture emerging from research reports, Chief Examiners Reports showed that students have difficulty in tackling some chemistry questions. According to the reports, the candidates' weaknesses among others are poor knowledge of concept of gases, poor mathematical skills in calculating moles, molar mass and percentage purity, inability to balance chemical equation.

The concern about performance of students in chemistry has led to several suggestions for improvement. Unfortunately, those suggestions revolve around the inappropriate teaching methods and inadequate practical exposure as the major cause of students' poor performance in chemistry. Chemistry, being an activity-oriented subject should be taught experimentally. Unfortunately, several contents cannot be taught with hands-on activities in the classroom, due to the hazardous nature of the experiments. Such experiments can be demonstrated and viewed in a classroom capable of displaying videos. Although some researchers like Apkan (2002) and Lunce (2006) have advocated the use of computer simulation which incorporates inquiry and cooperative learning in teaching science and mathematics. But to the best of the researcher's knowledge, no such study has been carried out in the area of gases. The present study is set to fill the gap.

\subsection{Purpose of the Study}

The purpose of this study was to determine the effect of computer simulations on secondary school students' achievement and interest in chemistry in Awka South Local Government Area. Specifically, the study sought to find out:

1. If difference exist between the mean achievement scores of students taught chemistry with computer simulations and that of those taught with lecture method.

2. There is difference between the mean achievements scores of students taught chemistry with computer simulation based of gender.

\subsection{Significance of the Study}

The results from this study are expected to be of benefit to many stakeholders in education and chemistry subject. These are chemistry teachers, students, curriculum planners and instructional material designers and developers.

The findings of the study will be useful to learners of chemistry because computer simulation was found effective in teaching chemistry. It helps the learners to learn some basic concepts on their own at their pace and time because they have access to the computer simulation software. From the findings, the use of this computer simulation software adapted from Physics Education and Technology (PhET) as a result of this study lead to raising student's interest in chemistry especially in those contents like gases that are almost impossible to practice through experimental activities in school laboratory. Learners' interest to engage in irrelevant programs such as video games when they are supposed to be reading their books might be transferred to a more productive and educative pursuit by using interesting simulation software.

The findings of the study were beneficial to chemistry teachers, most especially to chemistry teachers who served as the research assistants, because the computer simulations helped them to demonstrate chemistry concepts with ease and made their teaching of gases and matter practicable. They can, after being exposed to the package, 
try to develop other computer simulation for teaching other difficult topics in chemistry. It would also arouse the interest of chemistry teachers generally to embrace computer instruction as a worthwhile alternative approach towards effective teaching. It is hoped that the use of computer simulation will enable the teachers of chemistry to cover a wide range of topics within a short period of time without the teacher going through much stress. It will also help the teacher to arrange learning tasks from simple to complex.

\section{Research Questions}

The following research questions guided the study:

1. What are the differences in the mean achievement scores of students taught chemistry using computer simulations and those taught using lecture method?

2. What are the differences in the mean achievement scores of students taught chemistry using the computer simulations based on gender?

\subsection{Hypotheses}

The following null hypotheses which were tested at 0.05 level of significance provided focus to this study.

1. There is no significant difference between the mean achievement scores of students taught chemistry using computer simulations and those taught using lecture method.

2. There is no significant difference between the mean achievement scores of students taught chemistry using the computer simulations based on gender.

\section{Method}

The study adopted a quasi-experimental, non-equivalent control group design. The study was carried out in Awka South Local Government Area in Awka education zone of Anambra state, Nigeria. Anambra State is one of the 36 states of Nigeria and is located in the South-eastern part of the country. It lays approximately between latitudes 050481 and 060511 North of the equator and between longitudes 060381 and 070131 east of the Greenwich meridian. The inhabitants are mainly civil servants and traders. The native people are mainly known for blacksmithing.

The population of the study consists of all Senior Secondary Two (SS2) Chemistry students in 18 Public coeducational Secondary Schools in Awka South Local Government Area of Awka Education Zone of Anambra state numbering 1279 students (687 females and 592 males) enrolled for 2014/2015 academic session.

The sample consists of seventy-eight (78) SS2 students drawn from two schools out of the 18 co-educational secondary schools in the study area. The two schools were drawn purposively out of 18 schools because they have computer facilities. By flip of coin, one school was assigned experimental group and the other control group. Data were collected using a teacher-made test tagged Chemistry Achievement Test (CAT). Content validity of CAT was established using table of specification in which questions were distributed among three bloom taxonomy namely knowledge, comprehension and application. Reliability of the CAT was established using Kuder Richardson 20 (KR-20) because the items were dichotomously scored and this yielded a coefficient of 0.78. CAT has a total of 25 multiple choice questions on Gas Laws, State of Matter and Kinetic theories of gases.

Some of the questions in CAT are:

1. Which of the following relationships correctly expresses the Boyle's law? (A.) $\mathrm{P} \alpha \mathrm{V}$ at constant $\mathrm{T}$ (B.) $\mathrm{V} \alpha$ $\mathrm{T}$ at constant $\mathrm{P}$ (C.) $\mathrm{P} \alpha 1 / \mathrm{V}$ at constant $\mathrm{T}$ (D.) $\mathrm{V} \alpha 1 / \mathrm{T}$ at constant $\mathrm{P}$

2. Which of the following variables is a measure of the average kinetic energy of the molecule of a gas? (A.) Density (B.) Pressure (C.) Temperature (D.)Volume

3. The pressure exerted by a gas is a function of the (A.) total volume of the gas (B.) Speed of the gas eous molecules (C.) mass of each gaseous molecule (D.) frequency of collision between gaseous molecules.

4. Which of the following phenomena leads to decrease in volume of a liquid in an open container? (A.)Brownian motion (B.) Diffusion (C.) Evaporation (D.) Sublimation.

5. The gas law which describes the relationship between volume and temperature is (A.) Boyle's law (B.) Charles' law (C.) Dalton's law (D.) Graham's law.

6. The postulate that molecules are in constant random motion best explains why liquids (A.) can undergo solidification (B.) maintain their volumes (C.) are incompressible (D.)have no characteristic shape

While their answers are:

$\begin{array}{ll}\text { S/N } & \text { CORRECT ANSWERS } \\ 1 & \text { C } \\ 2 & \text { C } \\ 3 & \text { D } \\ 4 & \text { C } \\ 5 & \text { B } \\ 6 & \text { D }\end{array}$

The instructional tools that were used for teaching the students were the computer simulation models, the lesson plans and worksheets. The computer simulation models that were used were of two types namely; state of matter model and gas properties model. They were used respectively in teaching concepts of matter and concept of gases. The two models were adopted from online Physics Education Technology (PhET) interactive simulations (https://phet.colorado.edu/en/simulations/category/chemistry).

The students did not manipulate the simulations individually, but the teacher projected the simulations on the white board to create a virtual environment for the concepts he teaches. The concepts taught were state of matter and gas laws. 
Students were given pre-test after which they were subjected to treatment which lasted for four weeks. The state of matter was taught for two weeks while the gas laws specifically Boyle's law, Charles Law and Pressure law were taught for two weeks.

Thereafter, there was a post-test. Mean and standard deviation were used to answer the research questions while the hypotheses were tested using t-test and Analysis of Co-variance (ANCOVA).

\section{Results}

\section{Research Question 1}

What are the differences in the achievement mean scores of students taught chemistry using computer simulation and those taught using lecture method?

Table-1. Means and Standard Deviations of Pretest and Posttest Achievement Scores of Students in the Experimental and Control Group

\begin{tabular}{|c|c|c|c|c|c|c|}
\hline \multirow[b]{2}{*}{ Groups } & \multirow[b]{2}{*}{$\mathbf{N}$} & \multicolumn{2}{|c|}{ Pre-test Achievement } & \multicolumn{2}{|c|}{ Post-test Achievement } & \multirow[b]{2}{*}{ Gain in mean } \\
\hline & & $\operatorname{Mean}(\overline{\mathrm{X}})$ & S D & Mean $(\bar{X})$ & S D & \\
\hline Experimental & 38 & 14.95 & 11.03 & 57.21 & 5.53 & 42.26 \\
\hline Control & 40 & 15.05 & 10.76 & 41.40 & 7.66 & 26.35 \\
\hline
\end{tabular}

Source: SPSS analysis

Data presented in Table 1 show that the experimental group had a mean pretest achievement score of 14.95 and a mean posttest achievement score of 57.21. On the other hand, the control group had a mean pretest achievement score of 15.05 and a mean posttest achievement score of 41.40. It was observed from the table that the gain in mean achievement score of the experimental group (42.26) is higher than the gain in mean achievement score of the control group (26.35). This means that the group that was taught using computer simulation (experimental group) achieved more than the group that was taught using lecture method (control group) in chemistry.

\section{Research Question 2}

What are the differences in the mean achievement scores of male and female students taught chemistry using computer simulation?

Table-2. Means and Standard Deviations of Pretest and Posttest Achievement Scores of Male and Female Students in Experimental Group

\begin{tabular}{|c|c|c|c|c|c|c|}
\hline \multicolumn{4}{|c|}{ Pre-test achievement } & \multicolumn{3}{|c|}{ Post-test achievement } \\
\hline Gender & $\mathbf{N}$ & Mean X & S D & Mean X & S D & Gain in mean \\
\hline Male & 34 & 15.00 & 12.36 & 50.82 & 9.77 & 35.82 \\
\hline Female & 44 & 15.00 & 9.61 & 47.77 & 10.74 & 32.77 \\
\hline
\end{tabular}

Source: SPSS analysis

Data presented in Table 2 show that in experimental group, the male students have a pretest mean achievement score of 15.00 and posttest mean achievement score of 50.82. On the other hand, the female students have a pretest mean achievement score of 15.00 and posttest mean achievement score of 47.77 . It would be observed that the gain in mean achievement score of the male students (35.82) is higher than the gain in mean achievement score of the female students (32.77).

Table-3. Analysis of Covariance (ANCOVA) of Chemistry Students' Mean Achievement Scores by Teaching Method and Gender Tests of Between-Subjects Effects

\begin{tabular}{|c|c|c|c|c|c|}
\hline \multicolumn{6}{|c|}{ Dependent Variable: posttest } \\
\hline Source & Type III Sum of Squares & Df & Mean Square & $\mathbf{F}$ & Sig. \\
\hline Corrected Model & $4966.928^{\mathrm{a}}$ & 4 & 1241.732 & 27.252 & .000 \\
\hline Intercept & 63629.037 & 1 & 63629.037 & 1396.443 & .000 \\
\hline Pretest & .326 & 1 & .326 & .007 & .933 \\
\hline Method & 4590.956 & 1 & 4590.956 & 100.756 & .000 \\
\hline Gender & 66.653 & 1 & 66.653 & 1.463 & .230 \\
\hline Method * Gender & 28.430 & 1 & 28.430 & .624 & .432 \\
\hline Error & 3326.252 & 73 & 45.565 & & \\
\hline Total & 196356.000 & 78 & & & \\
\hline Corrected Total & 8293.179 & 77 & & & \\
\hline
\end{tabular}

a. $\mathrm{R}$ Squared $=.599$ (Adjusted R Squared $=.577)$

\section{Hypothesis One}

There is no significant difference between the mean achievement scores of students taught chemistry using computer simulation and those taught using lecture method.

The result in Table 3 indicates that the probability of obtaining the F-value (100.756) is zero (0.00), which is less than the 0.05 level of significance. The null hypothesis therefore is rejected, which means that there is a significant difference between the mean achievement scores of students in chemistry taught with computer simulation and those taught with lecture method in favor of experimental group with high mean score.

\section{Hypothesis Two}

There is no significant difference between the achievement mean scores students taught chemistry with computer simulation due to gender.

Table 3 indicates that the probability of obtaining the F-value $(0.143)$ is 0.230 , which is higher than the 0.05 level of significance. The null hypothesis therefore is upheld, which means that there is no significant difference 
between the mean achievement scores of male and female students taught chemistry with computer simulation and those taught with lecture method.

\section{Discussions}

\subsection{The Effect of Computer Simulation on Academic Achievement in Chemistry}

The findings of this study show that students taught chemistry using computer simulations performed better than students taught using lecture method. There is significant difference between the mean achievement scores of experimental group (computer simulation) and control group (lecture method) in favour of experimental group with higher mean. These findings appeared to be consistent with those of Kotoka and Kriek (2014) that students taught electromagnetism using computer simulation performed better than those taught with lecture method. Also Sentongo et al. (2013) findings aligned with the findings of the present study. They found that learners exposed with computer simulations performed better that those taught without computer simulations. Findings of Ezeudu and Okeke (2013) also confirmed the results of the present study. They found that simulations increase students' achievement in chemistry more than the lecture method.

The superiority of the computer simulation over the lecture method could be explained by the fact that computer simulation provided virtual laboratories and feedback on the chemistry concept. Computer simulation allows users to interact with it and minimizes abstractness of hazardous chemistry concept to the students. Students in experimental group were able to visualize, explore and formulate scientific explanations in chemistry that were otherwise impossible to observe and manipulate by students in control group. This implies that computer simulation improves students' achievement more when compared with lecture method.

\subsection{Influence of Gender on Academic Achievement in Chemistry}

The finding of this study reveals that mean achievement scores of male and female students taught chemistry using computer simulation were at the same achievement level. Also the finding indicates that gender did not influence students' achievement in chemistry significantly. These findings were in agreement with the findings of Ezeudu and Okeke (2013); Egara (2010); Udousoro (2011) that there is no significant difference in academic achievement of students in chemistry due to gender.

Contrary to the present findings was the report of Uwaleke (2013); Offiah and Egolum (2007). Among the results of Uwaleke' study was that female students perform better than male students in chemistry while Offiah and Egolum study revealed a significant gender difference on students' achievement in favour of males.

The difference in their performance can be attributed to gender stereotyping which encourage male and female students to show interest in subjects relevant and related to the roles expected of them in the society.

\section{Conclusion}

The study shows that computer simulation had significant effect on students' overall mean achievement in chemistry. The experimental group taught chemistry with computer simulation had higher mean achievement than the control group taught with lecture method.

The influence of gender on the students' academic achievement and interest in chemistry concepts studied was not significant.

\section{Recommendations}

Based on the findings of this study, the following recommendations were made:

1. Chemistry teachers should incorporate computer simulation as one of the methods used in teaching hazardous concepts in chemistry.

2. Computer simulation should also be used by chemistry teachers to enhance gender equity in achievement of all students in chemistry and other related disciplines.

3. The government should utilize the service of various bodies like the Science Teachers Association of Nigeria (STAN), Nigeria Union of Teachers (NUT), Chemical Society of Nigeria (CSN) and others to organise seminars, workshop and conferences to inform and train chemistry teachers and other science teachers on the use of computer simulation in teaching and learning.

\subsection{Limitations of the Study}

The researcher experienced the following as limitations in this study.

The use of only public coeducational secondary schools instead of private and public school as well as single sex schools in carrying out the study made it difficult to generalise the findings. Due to insufficient computers, students did not carried out the manipulation of the simulation individually.

\section{References}

Abdullahi, L., 2007. Procedural knowledge in the presence of a computer algebra system: Rating the drawbacks using a multi - factorial evaluation approach. International Journal for Technology in Mathematics Education, 14(1): 14 - 20. View at Google Scholar

Adyum, E., 2005. The use of computers in mathematics education: A paradigm shift from computer assisted instruction towards student programming. Turkish Online Journal of Educational Technology, 4(2): 27 - 34. View at Google Scholar

Apkan, J.P., 2002. Which comes first: Computer simulation of dissection or a traditional laboratory practical method of dissection. Electronic Journal of Science Education, 6(4): 1-20. View at Google Scholar

Chen, Y.L., P.R. Pan, Y.T. Sung and K.E. Chang, 2013. Correcting misconceptions on electronics: Effect of a simulation based learning environment backed by a conceptual change model. Educational Technology and Society, 16(2): $212-227$. View at Google Scholar

Clark, D.B., B. Nelson, P. Senguta and C. D’Angelo, 2009. Rethinking science learning through digital games and simulations: Genres, examples and evidence. Paper Presented at the National Research Council Workshop on Gaming and Simulation, Washington, DC.

Egara, O.F., 2010. Effect of computer simulation on achievement and interest of students in algebra at junior secondary school level. Unpublished Master's Thesis. University of Nigeria, Nsukka.

Ezeudu, F.O. and P.E. Okeke, 2013. Effect of simulation on students' achievement in senior secondary school chemistry in Enugu East local government area of Enugu State. Journal of Education and Practice, 4(19): 84 - 89. View at Google Scholar 
Kaheru, S.J., M. Mpeta and J. Kriek, 2011. The use of interactive computer simulations with regard to access to education - a social justice issue. Journal of Education Studies, 10(2): 89 - 106. View at Google Scholar

Kotoka, J. and J. Kriek, 2014. The impact of computer simulations as interactive demonstration tools on the performance of grade 11 learners in electromagnetism. African Journal of Research in Mathematics, Science and Technology Education, 18(1): 100 - 110. View at Google Scholar | View at Publisher

Lunce, L.M., 2006. Simulations: Bringing the benefits of situated learning to the traditional classroom. Journal of Applied Educational Technology, 3(1): 37-45. View at Google Scholar

Offiah, F.C. and E.O. Egolum, 2007. Effects of prior knowledge of some relevant mathematical concepts on students' achievement in stoichiometry. Journal of Science Engineering and Technology, 14(3): $7676-7685$.

Pierce, R. and K. Stacey, 2004. A framework for monitoring progress and planning teaching towards the effective use of computer algebra systems. International Journal of Computer for Mathematical Learning, 9(1): 59 - 93. View at Google Scholar $\mid$ View at Publisher

Plass, J.L., B.D. Homer and E.O. Hayward, 2009. Design factors for educationally effective animations and simulations. Journal of Computing in Higher Education, 21(1): 31 - 61. View at Google Scholar $\mid$ View at Publisher

Quellmalz, E., M. Timms, M. Silberglitt and B. Buckley, 2012. Science assessments for all: Integrating science simulations in to balanced state science assessment systems. Journal of Research in Science Teaching, 49(3): 363 - 393. View at Google Scholar |View at Publisher

Sentongo, J., R. Kyakulaga and I. Kibirige, 2013. The effect of using computer simulations in teaching chemical bonding: Experiences with Ugandan learners. International Journal of Education Science, 5(4): $433-441$. View at Google Scholar $\mid$ View at Publisher

Udousoro, U.J., 2011. The effects of gender and mathematics ability on academic performance of students in chemistry. An International Multidisciplinary Journal, Ethiopia, 5(4): 201 - 213. View at Google Scholar

Usman, K.O., 2002. Computer competencies required of mathematics teachers for the use of computer in teaching mathematics in Nigeria. (Unpublished Doctoral Dissertation). University of Nigeria, Nsukka.

Uwaleke, C.C., 2013. Analytical skill as a correlate of chemistry achievement among senior secondary school students in Anambra State. (Unpublished Master's Thesis). Nnamdi Azikiwe University, Awka. 